\title{
Study of Indonesia Exports with The Gravity Model Approach, 2001-2018
}

\author{
Dionisius Anindito Leksono ${ }^{1}$, Rogatianus Maryatmo ${ }^{2, *}$ \\ ${ }^{1,2}$ University of Atma Jaya Yogyakarta, Indonesia
}

\begin{abstract}
.
This study aims to examine the effect of GDP per capita, population, geographical distance, to Indonesia's exports. The data used in this study are annual data with a period of observation from 2001 to 2018 . The data are secondary data which are downloaded from 1 . The study was conducted on 20 trading partner countries of Indonesia. The trading partners studied sequentially are Australia, Bangladesh, China, Spain, Germany, Hongkong, India, Italia, Japan, South Korea Republic, Malaysia, Netherland, Pakistan, Philippine, Singapore, Taiwan, Thailand, United Kingdom, United States Of America, Vietnam. The analytical tool used is panel data regression which is processed using the EViews 10 software. The results show that GDP per capita and population have a significant positive effect on Indonesia's exports. The geographical distance between trading partners and Indonesia has a significant negative effect on Indonesian exports. Indonesia export is elastic to the economic growth distances, but not to the population of trading partners.
\end{abstract}

Keywords: gravity model, export, panel data

\section{Introduction}

The term gravity model in international trade comes from the laws of physics which are commonly known as Newton's law of gravity. Newton's law of gravity states that the gravitational force between two objects is proportionately affected by the mass of the two objects, but is inversely proportional to the distance between the two objects (Abidin, Haseeb, Chiat and Islam., 2016: 390). This theory develops in the field of economics. In the gravity model theory of international trade, mass is analogous to an economic measure such as GDP, GDP per capita, and population.

Research on the gravity model has been widely carried out in various fields of international trade. Research in the export sector was carried out by Abidin, Bakar and Sahlan (2013) and Feng, Zobel, Wu and Hodges (2019). Irshad, Xin, Hui, and Arshad (2018) and Ristanovic, Cogoljevic and Barjaktarevic (2017) researched the field of trading volume and value. In the import sector, the application of the gravity model is carried out by Truong, Dong and Nguyen (2019) and Ranilovic (2017).

One of the important explanatory variables that are often used in research using a gravity model is geographical distance. There are two possible directions for the influence of the distance variable on exports produced by previous research. The positive relationship between geographical distance and exports is supported by research by Lembang and Pratomo (2013), 


\section{$11^{\text {th }}$ International Conference on Modern Research in}

MANAGEMENT, ECONOMICS and ACCOUNTING

\section{8-20 December, 2020 Oxford, United Kingdom}

Waristi (2014) and Abidin, Bakar and Sahlan (2013). Meanwhile, the negative relationship is supported by the research of Demir, Bilik and Utkulu (2019), Ali (2013), Hyun and Jang (2019) and made clear in the research of Kaminchia (2019).

Population variables are also frequently used as an independent variable in gravity models. According to Ristanovic et al. (2017), the population of a country describes the purchasing power of the people. The bigger the purchasing power of the people, the bigger the international trade. The population has a positive relationship with the level of trade in a country (Demir et.al., 2019; Rasoulinezhad (2017). The findings of Farahmand and Zeraatkish (2019) show results that are contrary to the two studies above. Farahmand and Zeraatkish (2019) prove that there is a negative relationship between population and level of trade.

GDP (Gross Domestic Gross) is a calculation of the total expenditure on goods and services in an economy (Mankiw, 2018). The positive relationship between GDP per capita and trade is supported by the findings of Fejzic and Covrk (2016), Navarrete and Tatlonghari (2018), Wahyudi and Anggita (2015) and Gouveia, Rebelo and Gomes (2018). The finding of a negative relationship between GDP and the level of trade was revealed in research generated by Carolina and Aminata (2019).

Based on previous studies, this study chooses to analyze the effect of the GDP per capita, population and distance on the level of Indonesian exports. Using data on international trade in the top 20 export destination countries for Indonesia, multiple regression analysis using the gravity model approach was carried out.

\section{Theoretical Background and Literature Review}

The theory of gravity is one of the most frequently used concepts in analyzing international trade, especially in a bilateral context (Waristi, 2014). The gravity model is adopted from Newton's theory of gravity regarding the distance to the mass of an object. The same thing is also expressed by Fejzic and Covrk (2016) that the gravity model is part of the theory of international trade. According to them, in 1962 Jan Tinbergen proposed that the functional form of Newton's law could be applied to the flow of international trade. They argue that there are many variations in trading theory that the gravity equation cannot explain, but that there are several variables that can be used to explain trading. The following is a functional form of international trade theory according to Jan Tinbergen (Fejzic and Covrk, 2016):

$$
F_{i j}=G \frac{M_{i} M_{j}}{D_{i j}}
$$

The notation $\mid F_{i j}$ shows the trade flow or trade value from i to $\mathrm{j}$. The symbols $\mid M_{i}$ and $\mid M_{j}$ are GDP (Gross Domestic Product) of each location which represents the size of the economy in that location. The notation $D_{i j}$ is the distance between $\mathrm{i}$ and $\mathrm{j}$. According to Truong et al. (2019), the functional form created by Jan Tinbergen is not linear so it needs to be transformed into a linear equation.

In the research entitled "The Determinants of Exports between Malaysia and the OIC Member Countries: A Gravity Model Approach", Abidin et.al. (2013) argue that the main 


\section{$11^{\text {th }}$ International Conference on Modern Research in}

MANAGEMENT, ECONOMICS and ACCOUNTING

\section{8-20 December, 2020 Oxford, United Kingdom}

factors affecting Malaysian exports to OIC countries are the size of the economy, the level of openness of a country, inflation and exchange rates. This study uses a fixed-effect model. The GDP variable in OIC member countries has a positive effect on Malaysian exports. Different results were obtained for the GDP per capita variable which had a negative effect on Malaysian exports. The difference in the sign is due to the dominant effect of economies of scale rather than the absorption effect in OIC member countries.

A gravity model research has also been carried out in the northern African continent by Ali (2013). According to Ali (2013), another factor that affects trade between countries is maritime boundaries. His findings indicate that Tunisia trades more frequently with its closest countries and with countries that share maritime boundaries. This conclusion is supported by the fact that international trade is mostly carried out by the sea. Other factors, such as an increase in the GDP of Tunisia's trading partner countries, have a positive effect on Tunisian exports.

Lembang and Pratomo (2013) also use a gravity model in their research on the factors that influence Indonesia's rubber exports to 15 major trading partner countries after the implementation of the ACFTA policy. The results showed that Indonesia's GDP per capita did not affect rubber exports to fifteen (15) trading partner countries. This happened because the increase in GDP per capita of the Indonesian people was not allocated much for expenses that support rubber production. On the other hand, the GDP per capita of these fifteen countries has a significant and positive effect on Indonesia's rubber exports.

Mjema and Mahona (2014) analyzed the determinants of trade flows between Tanzania and Kenya. The results showed that GDP per capita of Tanzania has a negative relationship with the total value of trade. This implies that the Tanzanian trade pattern is following a GDP pattern rather than a per capita pattern. This is because Tanzania's trade is categorized as a small country that depends on the income level of its trading partners. The difference in the coefficient of distance that is lower than previous studies implies that the cost, barriers to market access in Tanzania are better than that of its neighbours. The variable of country openness in this study shows positive results, this indicates that openness or liberalization determines the export performance of Tanzania.

Research by Karno (2017) discusses the opportunities and constraints of Indonesia's exports to various countries in Asia using a gravity model approach. The research was conducted using panel data. Cross-section data using a sample of Asian countries. Time series data use annual data with a period from 1987 to 2014. The results of this study indicate that GDP has a positive influence on Indonesia's exports. A positive relationship is also shown by GDP per capita to exports. The variable of economic growth in ASEAN countries also encourages an increase in Indonesia's exports to these countries. Foreign direct investment (FDI) in this study does not affect Indonesia's exports to ASEAN countries. Exchange rate flux has a positive effect on Indonesian exports. The inflation rate in trading partner countries has been shown to increase Indonesia's exports. Karno's research (2017) also concluded that distance has a negative and significant effect on Indonesia's trade with various countries in Asia. The closer the distance is, the lower the cost of exporting goods and vice versa. Economic cooperation relations within ASEAN have also had a positive influence on Indonesia's exports. 


\section{$11^{\text {th }}$ International Conference on Modern Research in}

MANAGEMENT, ECONOMICS and ACCOUNTING

\section{8-20 December, 2020 Oxford, United Kingdom}

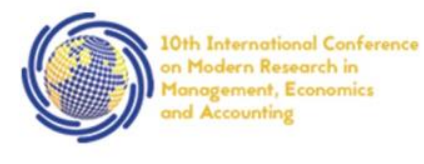

Ranilovic's research (2017) concluded that the factors of the split state of Yugoslavia provided a positive relationship with both Croatian exports and imports. This study uses 5 approaches at once, namely; OLS (Ordinary Least Square), fixed effects, random effects, PPML (Poisson Pseudo Maximum Likelihood), and dynamic models. The results of this study are that the GDP of Croatia and trading partner countries in this study have a positive and significant effect on Croatian exports and imports to the European Union. GDP gives a greater yield on the import model than the export model. Distance as an indicator of transportation costs shows a negative and significant relationship. However, distance as a transportation cost affects Croatian exports more than imports. Croatia's membership in the European Union has had a positive and significant impact on both exports and imports. Croatia's membership in the European Union affects imports more than exports. The effect of economic cooperation in the CEFTA leads to different conclusions. Membership in the CEFTA generates a positive and significant relationship to exports. Membership in the CEFTA does not significantly affect Croatian imports from CEFTA countries.

Demir et al. (2019) analyzed the convergence in the efficiency of manufacturing trade between Turkey and 25 European Union countries. In this study, the GDP of Turkey and the European Union countries have a positive relationship with manufacturing trade. Population variables also have a positive effect on trade. Larger populations in importing countries encourage imported goods to compete better with domestic goods. The time dummy variable has a negative effect, which indicates that Turkey's trading activities are affected by the global crisis. Not much different from the results of the gravity model research in general, distance has a negative relationship to Turkey's trade volume. The greater the distance between the two countries, the more transportation costs tend to increase and trade volume decreases. In this study, the trade freedom index has a positive effect on exports and a negative effect on imports. Countries that impose trade borders cause trade activities to decrease significantly.

\section{Research Methodology}

This study uses data on Indonesia's exports to the top twenty (20) destination countries for Indonesian exports, GDP per capita, population, and distance taken from the publication of the International Monetary Fund published in 2018 (IMF, 2018). The analytical tool used in this study is panel data regression analysis using the Eviews 10 software. The panel multiple regression model specified is as written in equation (2) below.

$$
L N E K S P O R_{i j t}=\beta_{0}+\beta_{1}\left(L N G D P P_{j t}\right)+\beta_{2}\left(L N P O P_{j t}\right)+\beta_{3}(L N J A R A K)+\epsilon_{t}
$$

Variable $L N E K S P O R_{i j t}, L N G D P P_{j t}, L_{L N P O P_{j t}}$, consecutively are export value, GDP, and population of the top twenty countries destination of Indonesia export; and $L N J A R A K$ is the distance of the top of twenty countries export destination and Indonesia. Notation of $\beta_{0}, \beta_{1}$, $\beta_{2}$ represents the coefficient elasticity of exports. The symbol of $\epsilon_{t}$ identifies the residual value of Ordinary Least Squares. The top of twenty countries export destination of Indonesia sequentially is Australia, Bangladesh, China, Spain, Germany, Hongkong, India, Italia, Japan, 


\section{$11^{\text {th }}$ International Conference on Modern Research in}

\section{MANAGEMENT, ECONOMICS and ACCOUNTING}

\section{8-20 December, 2020 Oxford, United Kingdom}

South Korea Republic, Malaysia, Netherland, Pakistan, Philippine, Singapore, Taiwan, Thailand, United Kingdom, United States Of America, Vietnam.

There are several estimation models in the Data Regression Models Panel. The choices of a model depend on two interests, namely the interests of research objectives and better fit data. There are three possible models to choose from. The three models are the common effect model, the fixed-effect model, and the random effect model. For the choice of the best model, the model specification test is carried out. The model specification test was carried out by using the Chow test and Hausmann test. Other statistical tests are the t-test and F test (Gujarati and Porter, 2009)

\section{Research Result and Discussion}

The focus of this research is to test that the theory of Gravity applies to international trade in Indonesia. In other words, this research will prove that the GDP, population, and distance variables affect the value of Indonesia's exports to 20 destination countries. For this purpose, the Common effect model is the most appropriate (Ariefianto, 2012: 150). Table 1 is the results of the regression of the common effects model.

Table 1: Common Effect Estimation

\begin{tabular}{|c|c|c|c|c|}
\hline Variable & Coefficient & Std. Error & t-Statistic & Prob. \\
\hline C & 1.388751 & 0.436456 & $3.181883^{*}$ & 0.0016 \\
\hline LNGDPP & 1.233289 & 0.041925 & $2.941678^{*}$ & 0.0000 \\
\hline LNPOP & 0.836481 & 0.032016 & $2.612668^{*}$ & 0.0000 \\
\hline LNJARAK & -1.057583 & 0.048804 & $-2.167015^{*}$ & 0.0000 \\
\hline R-squared & & 0.724668 & \\
\hline Sum squared resid & & 109.1799 & \\
\hline F-statistic & & $312.3274^{*}$ & \\
\hline Prob $($ F-statistic $)$ & & 0.000000 & \\
\hline
\end{tabular}

Sources : Research Data Calculated (*statistically significant in $\alpha=0.01 \%$ )

After getting the estimation results, the next step is the classical assumption test, namely the multicollinearity test and heteroscedasticity, and autocorrelation test. After the tests and treatment of the classical assumption violation, the free-classical assumption violations estimation could be presented in table2.

Table 2: Estimation Results of Free-Classical Assumption Violations

\begin{tabular}{|c|r|r|c|c|}
\hline Variable & Coefficient & Std. Error & t-Statistic & Prob. \\
\hline
\end{tabular}


$11^{\text {th }}$ International Conference on Modern Research in

MANAGEMENT, ECONOMICS and ACCOUNTING

\section{8-20 December, 2020 Oxford, United Kingdom}

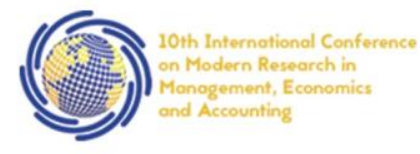

\begin{tabular}{|c|c|c|c|c|}
\hline C & 0.945271 & 0.306563 & $3.083454^{*}$ & 0.0022 \\
\hline LNGDPP & 1.284367 & 0.028286 & $4.540656^{*}$ & 0.0000 \\
\hline LNPOP & 0.884443 & 0.020895 & $4.232823^{*}$ & 0.0000 \\
\hline LNJARAK & -1.092026 & 0.031570 & $-3.459024^{*}$ & 0.0000 \\
\hline$R$-squared & \multicolumn{5}{|c|}{0.868342} \\
\hline Sum squared resid & \multicolumn{5}{|c|}{106.5875} \\
\hline$F$ - statistic & \multicolumn{5}{|c|}{$782.6614^{*}$} \\
\hline Prob (F-statistic) & \multicolumn{5}{|c|}{0.000000} \\
\hline
\end{tabular}

Sources : Research Data Calculated (*Statistically significant in $\alpha=0.01$ )

From table 2, it could be described that all gravity variables such as GDP, population, and distance to the country export destination partially and simultaneously well explain the value of Indonesia export. GDP of the country-export destination has a positive and significant impact on Indonesia export. GDP of the export-destination countries represents the purchasing power of the countries to Indonesia export. The finding is concordance with the research of Abidin et.al. (2013), Ali (2013), Karno (2017), Ranilovic's research (2017).

The population of the export-destination countries have positively and significantly impact to Indonesia export. The population suggests the size market of the countries. The bigger the population the higher the export is. The conclusion is similar to that of Ranilovic's research (2017).

As predicted by the theory of gravity, the distance has a negative influence on Indonesia export. The farther the distance, the lower the export value of Indonesia to the countries is. The distance implies that the closer the distance the lower the transport cost is. The lower the transport cost, the higher the export value is. The research result is supported by that of Mjema and Mahona (2014), Ali (2013), Karno (2017).

Indonesia's export is elastic to the change in GDP, and the distance of the exportdestination countries. It implies that Indonesia has enough production capacity. If the GDP, population and distance of export-destination countries increase by one percent, Indonesia export increases more than one percent. Indonesia's export is not elastic to the change in population. Indonesia export is the most elastic to GDP of export-destination countries.

The conclusion of this study is important for government recommendation. To promote exports, the government should focus on their export target to neighbouring countries with high economic growth. Promotion and encouragement of exports to neighbouring countries and countries with high economic growth need to be accelerated.

\section{Conclusion}

GDP, population, and geographical distance have a significant effect on Indonesian exports. GDP and the population have a positive effect on exports. Distance harms Indonesian exports. Exports are very elastic to the changes in GDP and the distance to the export- 
$11^{\text {th }}$ International Conference on Modern Research in

MANAGEMENT, ECONOMICS and ACCOUNTING

\section{8-20 December, 2020 Oxford, United Kingdom}

destination countries. Exports are inelastic to the change in the population of the export destination countries. Since exports are elastic to GDP and Distance, to promote exports the government should focus their export target to the neighbouring countries with high economic growth.

\section{Acknowledgment}

I owe to the Economics Department, Faculty of Economics and Business, and University of Atma Jaya Yogyakarta who has funded and facilitated us to accomplished the research and writing this paper. Without their support, this research and paper will not be possible.

\section{References}

Abidin, I. Z. et.al, (2013). The Determinants Of Exports Between Malaysia And The OIC Member Countries : A Gravity Model Approach. Procedia Economics And Finance, Vol. 5, pp 12 - 19.

Abidin, I. Z. et.al.,(2016). Determinants Of Malaysia - BRICS Trade Linkages: Gravity Model Approach. Investment Management And Financial Innovations, Vol. 13, Iss. 2, pp 389 - 398.

Ali, M. (2013). Determinants Of Tunisia's Exports : A Gravity Model Framework. International Journal Of Economic Perspectives, Vol. 7, Iss. 1, pp 51-60.

Ariefianto, M. D. (2012). Basic Econometrics, and It's Applications Using Eviews.(translated) Jakarta: Erlangga Publisher.

Carolina, L., and Aminata, J. (2019). Analysis of Competitiveness and Factors Affecting Coal Exports (translated). Diponegoro Journal Of Economics, Vol. 1, Iss.1, pp 9-21.

Demir, M. A. et.al., (2019). The Efficiency Of Manufacturing Trade Between Turkey And The European Union. Business \& Management Studies : An International Journal, Vol.7, Iss. 2, pp 591 - 608.

Farahmand, Z., and Zeraatkish, S. Y. (2019). The Effect Of Economic Sanctions On The Volume Of Trade In The Agriculture Sector Of Iran And Business Partners In The European Union. Economic Journal Of Emerging Markets, Vol. 11, Iss. 1, pp 97 103.

Fejzic, A., and Covrk, E. (2016). Infrastructure, Transport Cost, And Bosnia And Herzegovina's Trade : A Gravity Model Approach. Ekonomski Vjesnik / Econviews, Vol. XXIX, pp 77 - 90.

Feng, X. et.al., (2019). Do China's Plywood Exports Depend On Trade Partners? Evidence From The Gravity Model. Forest Products Journal, Vol. 69, Iss. 1, pp 26 - 33. doi:10.13073/FPJ-D-18-00032 
$11^{\text {th }}$ International Conference on Modern Research in

MANAGEMENT, ECONOMICS and ACCOUNTING

\section{8-20 December, 2020 Oxford, United Kingdom}

Gouveia, S. et.al., (2018). Port Wine Exports: A Gravity Model Approach. International Journal Of Wine Business Research, Vol. 30, Iss. 2, pp 218-242. www.emeraldinsight.com/1751-1062.htm

Gujarati, D. N., and Porter, D. C. (2009). Basic Econometrics. New Delhi: Tata Mcgraw-Hill Education.

Hyun, H. J., and Jang, Y. J. (2019). New Trade Restrictive Measures And Exports : Evidence From South Korea. Seoul Journal Of Economics, Vol. 32, Iss. 2, pp 138 - 162.

Irshad, M. S. et.al., (2018). An Empirical Analysis Of Pakistan's Bilateral Trade And Trade Potential With China : A Gravity Model Approach. Cogent Economics \& Finance, pp 1 - 18. https://doi.org/10.1080/23322039.2018.1504409

Kaminchia, S. M. (2019). The Determinants Of Trade Costs In The East African Community. Journal Of Economic Integration, Vol. 34, Iss. 1, pp 38 - 85. DOI: HYPERLINK "https://doi.org/10.11130/jei.2019.34.1.038" https://doi.org/10.11130/jei.2019.34.1.038

Karno, K. (2017). Gravity Modeling Approach For Indonesia's Exports With Ten Asian Countries. International Journal Of Economics And Business Administration, Vol. V, Iss. 3, pp 3-20.

Lembang, M., and Pratomo, Y. (2013). Indonesian Rubber Exports to the 15 Main Destination Countries, Trikonomika, Vol. 12, Iss. 1, pp 20-31.

Mankiw, N. G. (2016). Macroeconomics, $9^{\text {th }}$ ed., Worth Publisher, New York

Mahona, B. K and Mjema G., . (2014). Determinants Of East African Community Trade: A Gravity Model Analysis Of Trade Flows Between Tanzania And Kenya. Journal of Economics And Sustainable, Vol. 5, Iss. 4, pp 13 - 23. www.iiste.org

Navarrete, A. C., and Tatlonghari, V. M. (2018). An Empirical Assessment Of The Effects Of The Japan Philipphine Economic Partnership Agreement (JPEPA) On Philipphine Exports To Japan : A Gravity Model Approach. Journal Of Economic Structure, Vol. 7, Iss. 31, pp 2 - 20 https://doi.org/10.1186/s40008-018-0129-8

Ranilovic, N. (2017). The Effects Of Economic Integration On Croatian Merchandise Trade : A Gravity Model Study. Comparative Economic Studies, Vol. 59, pp 382 - 404. www.palgrave.com/journals

Rasoulinezhad, E. (2017). Iran's Trade Modification Under Sanctions: An Evidence Of Trade Divergence And Trade Convergence Through The Gravity Model. Journal of Economic Cooperation And Development, Vol. 38, Iss. 4, pp 25 - 56. 
$11^{\text {th }}$ International Conference on Modern Research in

MANAGEMENT, ECONOMICS and ACCOUNTING

\section{8-20 December, 2020 Oxford, United Kingdom}

Ristanovic, V. et. al., (2017). Direction Of Serbian Trade: Gravity Model Based On Pool Data. Euro Economica, Vol. 1, Iss. 36, pp 21 - 33.

Truong, H. Q. et. al., (2019). Determinants Of Trade Flows And Trade Structure Between Korea And ASEAN. East Asian Economic Review, Vol. 23, Iss. 1, pp 55 - 88. http://dx.doi.org/10.11644/KIEP.EAER.2019.23.1.356

Wahyudi, S., and Anggita, R. (2015). The Gravity Model Of Indonesian Bilateral Trade. International Journal Of Social And Local Economic Governance, Vol. 1, Iss. 2, pp $153-156$.

Waristi, F. (2014). The Influence of Religion and Culture on Indonesia's Bilateral Trade with Asean Member Countries, Economic and Financial Studies (translated), Vol. 18, Iss. 2, pp 85-98.

Widarjono, A. (2013). Introduction to Econometrics and Its Applications (translated), Yogyakarta: UPP STIM YKPN. 